\title{
TUITION TAX CREDITS AND THE MARKET FOR PRIVATE SCHOOLING IN NORTH CAROLINA
}

\author{
G. Donald Jud*
}

Over the past several decades, a number of proposals have been made to provide federal tuition tax credits (or publicly funded educational vouchers) to parents who send their children to private elementary and secondary schools. The Reagan Administration has repeatedly pledged its support to this effort, and in 1983, a Gallup Poll for the first time showed that a slight majority of the public favored a voucher plan.

The estimated costs of such plans and their effects on public school enrollments have been debated widely, but agreement has been lacking. Proponents like Milton Friedman (Friedman and Friedman, 1981, pp. 148-65) have advanced the idea as a way to promote competition among schools and to give all parents, even poor ones, a wider range of choice. Opponents, on the other hand, have charged that the plan would destroy the public schools and foster further stratification of the educational system by race and social class (see, for example, New York Times, 1981).

Recent empirical studies by Erekson (1982) and Frey (1982) illustrate some of the divergent effects that have been estimated. Erekson's study, based on a sample of school districts in New York state in 1970, concluded that tuition tax credits would have little effect on demand because the price elasticity was extremely low. For parochial education, he found that the tuition price had no effect at all on enrollment, and for nonparochial, private schools, he estimated a price elasticity of only -0.21 .

Frey reported a price elasticity for private schools of -0.4 , using pooled time-series and cross-sectional data for states for 1976-78. Unlike Erekson, Frey also considered supply effects. He estimated separate supply elasticities for private schooling at the elementary and secondary levels. For elementary schools, he found the supply elasticity to be quite low $\left(\epsilon_{\mathrm{g}}=0.24\right)$, while for secondary education, he reported that supply was price elastic $\left(\epsilon_{\mathrm{s}}=1.95\right)$. Because of

\footnotetext{
*University of North Carolina, Greensboro. Special thanks are due Ms. Pat Schultz and Mr. Wayne McClanahan for assistance in collecting and tabulating sample data.
}

the low supply elasticity for elementary schools, Frey concluded that tax credits would force a substantial rise in elementary tuition: Much of the tax credit would be absorbed by private elementary schools. He calculated that a 50 percent credit would increase private elementary enrollment by only 10 percent. At the secondary level, however, a 50 percent credit would raise private enrollment by 18 percent.

This paper develops estimates of the impact of tuition tax credits on private school enrollment within the state of North Carolina. Data for the study were obtained from a 1980 survey of private elementary and secondary schools. The price and income elasticities of demand are found to be in the inelastic range, and the price elasticity of supply for elementary and secondary schooling combined is found to be very elastic. The paper shows that overall tax savings could result from a tuition tax credit program. The first section of the paper develops a model of market demand and supply for private schools. Section II presents the empirical estimates. Section III uses the estimated empirical model to simulate the effects of tuition tax policies. The final section provides a brief summary of findings and results.

\section{I.}

The basic assumption underlying this analysis is that private elementary and secondary schooling is produced and sold under conditions which are roughly similar to that of a market. Parents are assumed to be responsive in the demands for their childrens' schooling to the level of private school tuition. And private schools are assumed to offer schooling at roughly average cost. The market mechanism is assumed to function such that the quantity of schooling supplied is roughly equated to the quantity demanded.

The analytical model can be described as follows:
1) $q_{p}=f(p, x)$
2) $\mathrm{p}=\mathrm{f}\left(\mathrm{q}_{\mathrm{s}}, \mathrm{z}\right)$.
3) $q_{\mathrm{D}}=\mathrm{q}_{\mathrm{s}}$
Demand Supply 
where $q_{D}$ and $q_{s}$ are the quantities demanded and supplied; $p$ is the price of private school; and $x$ and $z$ are other relevant determinants of demand and price.

In addition to price, or tuition, the market demand for private schooling is assumed to be influenced by the average income of consumers, the size of the school-age population, and the perceived quality and availability of private and public schools. Other factors, such as religious preference and racial prejudice, are assumed to affect the decisions of some parents to enroll their children in private school.

On the supply side of the market, the supply price of private schooling, or average tuition, is taken to be a positive function of enrollment, the quality and coverage of private schools, and the costs of other inputs. School religious affiliation is assumed to be associated with lower tuition, since many denominations subsidize their private schools.

II.

The basic data for this study were obtained for 1980 from the Office of Non-Public Education for the State of North Carolina. ${ }^{1}$ This office publishes an annual directory of non-public schools. The directory lists every private school, showing the public school district in which the school is located, its enrollment, staff, religious affiliation and the grade levels it offers.

Tuition information was obtained from a direct mail and telephone survey of schools. In 1980 , there were 339 private schools offering education to non-boarding students. The survey provided tuition information for 259 of these schools (a response rate of 76 percent). These 259 schools were responsible for 85 percent of the state's total private school enrollment.

Schools were questioned regarding their basic tuition, special fees, and the required bond or deposit, if any. For each school, a tuition price was calculated that included basic tuition, special fee, and 10 percent of any bond or deposit. If tuition varied by grade level, the median grade-level was used. Where churchaffiliatied schools charged different rates for members and non-members, the tuition price was the average of the member and non-member rates. Some schools offered discounts for more than one child. In this case, census estimates of the average number of children per household in the county were used to calculate an average price per child.
The model of market demand and supply described in equations (1)-(3) was estimated using observations that represented weighted averagees of private schools within individual public school districts. Enrollment in each school was used to determine its weight in the district average. This procedure assumed that the market area of each private school was the public school district in which the school was located, and district averages were constructed to represent market conditions. Survey data were obtained from 89 of the 106 public school districts in which private schools operated.

The survey of schools plus the 1980 Census provided data for the following eight variables within each of the 89 districts:

$$
\begin{aligned}
\mathrm{T}_{\mathrm{i}}= & \text { average private school tuition, } \\
\mathrm{E}_{\mathrm{i}}= & \text { total enrollment in all private } \\
& \text { schools in the district, } \\
\mathrm{Y}_{\mathrm{i}}= & \text { average per capita income, } \\
\mathrm{Q}_{\mathrm{i}}= & \text { average number of staff per grade } \\
& \text { level, } \\
\mathrm{G}_{\mathrm{i}}= & \text { average number of grade levels } \\
& \text { offered, } \\
\mathrm{C}_{\mathrm{i}}= & \text { church affiliation }(1=\text { no, } 2= \\
& \text { yes), } \\
\mathrm{N}_{\mathrm{i}}= & \text { total size of the school age } \\
& \text { population, } \\
\mathrm{U}_{\mathrm{i}}= & \text { percent urban population. }
\end{aligned}
$$

The specific formulations of the market demand and supply models were:

(4) $\mathrm{E}_{\mathrm{i}}=\mathrm{f}\left(\mathrm{T}_{\mathrm{i}}, \mathrm{Y}_{\mathrm{i}}, \mathrm{Q}_{\mathrm{i}}, \mathrm{G}_{\mathrm{i}}, \mathrm{N}_{\mathrm{i}}, \mathrm{U}_{\mathrm{i}}\right)$ Demand

(5) $\mathrm{T}_{\mathrm{i}}=\mathrm{f}\left(\mathrm{E}_{\mathrm{i}}, \mathrm{Q}_{\mathrm{i}}, \mathrm{G}_{\mathrm{i}}, \mathrm{C}_{\mathrm{i}}, \mathrm{U}_{\mathrm{i}}\right)$ Supply

$Q_{i}$ and $G_{i}$ were included both in the demand and supply functions as measures of the quality and availability of private schooling. The urbanization variable $\left(U_{i}\right)$ was used in the supply function as a proxy for the cost of other private school inputs.

In the demand function, $U_{i}$ was employed as a proxy for several analytically separable, but mutually related effects. First, urban public school districts are administratively more complex, making communication between parents and administrators more difficult, and increasing the possibility that some parents dissatisfied with public school policy will withdraw. Related to this problem is the fact that urban districts usually are required to serve a heterogenous mix of students, making it harder for the administration to tailor a curriculum that satisfies the expectations of all groups. William A. Niskanen (1980) has argued, for example, 
that a major problem of large public districts is that they usually attempt the uniform provision of schooling services to urban populations that have significantly varied preferences for the level and character of public education. Larger urban districts also are likely to have been involved in extended court-ordered desegregation disputes which disrupted the public schools and, thereby, increased the demand for private education. The studies by Coleman (1975), Clotfelter (1979), and Armor (1980) clearly show that desegregation stimulated the flight of whites from public schools, especially in larger cities. And it seems clear that some of these white parents transfered their children to private school rather than relocate in the suburbs.

The estimated demand model contained no measure of religious preference. This omission reflected programmatic empiricism, not the conviction that religious preference had no effect on private school demand. Initial experiments with various measures of religious affiliation normally thought to be associated with increased demand for private schooling showed that these measures did not significantly improve the explanatory power of the model. This result may simply reflect the religious preferences of North Carolina's population. Catholics, who normally are the largest consumers of parochial education, represent only a small fraction of the total population, and there is relatively little variation in religious preference across counties.

Prior to estimation, data for all variables were transformed to natural logarithms. Estimates of the model using logarithmic data are shown in Table 1.

Since the tuition and other school data were weighted averages of private schools located within public school districts, sampling errors were likely to be larger in those districts where the number of private schools in the sample was small. To compensate, the regression equations were weighted by the number of sample schools in each district. ${ }^{2}$

Looking at Table 1, all variables have the expected signs and most are statistically significant at reasonable probability levels. Both the absolute value and the t-ratio of the tuition coefficient were increased when the demand model was estimated using simultaneous esti-

TABLE 1.

The Market for Private Elementary and Secondary Schooling (t-values in parenthesis)

\begin{tabular}{|c|c|c|c|c|c|c|}
\hline \multirow[b]{3}{*}{ Dep. Var. } & \multicolumn{2}{|c|}{$\begin{array}{c}\text { Ordinary } \\
\text { Least Squares }\end{array}$} & \multicolumn{2}{|c|}{$\begin{array}{c}\text { Two Stage } \\
\text { Least Squares }\end{array}$} & \multicolumn{2}{|c|}{$\begin{array}{c}\text { Three-Stage } \\
\text { Least Squares }\end{array}$} \\
\hline & Demand & Supply & Demand & Supply & Demand & Supply \\
\hline & $\mathrm{E}_{1}$ & $\mathrm{~T}_{\mathrm{i}}$ & $\mathbf{E}_{\mathrm{i}}$ & $T_{i}$ & $E_{i}$ & $\mathrm{~T}_{\mathrm{i}}$ \\
\hline Constant & $\begin{array}{r}-90.45^{*} \\
(2.57)\end{array}$ & $\begin{array}{r}6.65^{*} \\
(22.56)\end{array}$ & $\begin{array}{c}-7.08^{* *} \\
(1.68)\end{array}$ & $\begin{array}{c}6.52^{*} \\
(20.75)\end{array}$ & $\begin{array}{c}-7.42^{* *} \\
(1.78)\end{array}$ & $\begin{array}{r}6.52^{*} \\
20.75 \text { ) }\end{array}$ \\
\hline $\mathrm{T}_{\mathrm{i}}$ & $\begin{array}{c}-0.10 \\
(0.46)\end{array}$ & - & $\begin{array}{c}-0.53^{* *} \\
(1.32)\end{array}$ & - & $\begin{array}{c}-0.52 * * \\
(1.32)\end{array}$ & - \\
\hline $\mathbf{E}_{\mathrm{i}}$ & - & $\begin{array}{l}0.08^{*} \\
(2.03)\end{array}$ & - & $\begin{array}{r}0.17^{*} \\
(2.76)\end{array}$ & - & $\begin{array}{l}0.17^{*} \\
(2.76)\end{array}$ \\
\hline$Y_{i}$ & $\begin{array}{c}0.79 * \\
(2.30)\end{array}$ & - & $\begin{array}{l}0.82^{*} \\
(2.32)\end{array}$ & - & $\begin{array}{l}0.85^{*} \\
(2.44)\end{array}$ & - \\
\hline $\mathbf{Q}_{\mathrm{i}}$ & $\begin{array}{l}1.15^{*} \\
(9.42)\end{array}$ & $\begin{array}{l}0.11^{* *} \\
(1.50)\end{array}$ & $\begin{array}{c}1.27^{*} \\
(8.07)\end{array}$ & $\begin{array}{c}0.06 \\
(0.52)\end{array}$ & $\begin{array}{r}1.27^{*} \\
(8.06)\end{array}$ & $\begin{array}{l}0.06 \\
(0.52)\end{array}$ \\
\hline $\mathrm{G}_{\mathrm{i}}$ & $\begin{array}{c}1.20^{*} \\
(4.20)\end{array}$ & $\begin{array}{c}0.02 \\
(0.16)\end{array}$ & $\begin{array}{l}1.29 * \\
(4.28)\end{array}$ & $\begin{array}{c}0.13 \\
(0.82)\end{array}$ & $\begin{array}{c}1.29 * \\
(4.30)\end{array}$ & $\begin{array}{c}0.13 \\
(0.82)\end{array}$ \\
\hline $\mathrm{C}_{\mathrm{i}}$ & - & $\begin{array}{c}-0.69 * \\
(5.56)\end{array}$ & - & $\begin{array}{r}-0.80^{*} \\
(5.68)\end{array}$ & - & $\begin{array}{c}-0.80 * \\
(5.68)\end{array}$ \\
\hline $\mathbf{N}_{\mathrm{i}}$ & $\begin{array}{c}0.48^{*} \\
(6.01)\end{array}$ & - & $\begin{array}{c}0.49^{*} \\
(5.96)\end{array}$ & - & $\begin{array}{c}0.48^{*} \\
(5.92)\end{array}$ & - \\
\hline $\mathrm{U}_{\mathrm{i}}$ & $\begin{array}{l}0.31 * * \\
(1.52)\end{array}$ & $\begin{array}{l}0.15^{* *} \\
(1.75)\end{array}$ & $\begin{array}{c}0.36^{*} \\
(1.67)\end{array}$ & $\begin{array}{l}0.14^{* *} \\
(1.51)\end{array}$ & $\begin{array}{c}0.36^{*} \\
(1.66)\end{array}$ & $\begin{array}{c}0.14^{* *} \\
(1.51)\end{array}$ \\
\hline $\mathbf{R}^{2}$ & 0.98 & 0.65 & 0.89 & 0.64 & 0.86 & 0.86 \\
\hline
\end{tabular}

Asterisks indicate significance of coefficients (one-tailed test):

$*>.05$

$* *>.10$ 
mation techniques. Thus, tuition and enrollment appear to be simultaneously determined, as postulated in the model shown in equations (1)-(3).

The estimates of the income and price elasticitics of demand show these elasticitics to be in the inelastic range. These results conform to those reported by Rubinfeld (1977) in his study of the demand for public education. Rubinfeld also reported that the ratio of the income to the price elasticity of demand for public education was - 1.7. The two- and three-stage least squares estimates shown in Table 1 yield elasticity ratios for private education that are very close to those found by Rubinfeld for public education. The income-price elasticity ratio for the 2SLS model is -1.54 and that of the 3SLS model is -1.63 .

The estimated supply model in Table 1 is an inverse supply function. Accordingly, the elasticity of supply can be found by taking the reciprocal of the enrollment coefficient. This yields an estimate of the elasticity of supply for private schooling that is very elastic. The supply elasticity estimated in both the 2SLS and 3SLS models is 5.88 . Such an elastic supply function suggests that most private schools are operating in a range where there are few diseconomies of scale. The lack of strong diseconomies of scale in private education accords with results reported in previous empirical studies of public elementary and secondary schools (see Cohn (1979), pp. 202-203).

\section{III.}

Figure 1 shows a graph of the demand $\left(D_{0}\right)$ and supply $\left(\mathrm{S}_{\mathrm{o}}\right)$ schedules obtained from the estimated 3SLS model, using the mean values of all independent variables. The equilibrium tuition rate is $\$ 966$ per year of private schooling and the equilibrium private enrollment in the average public school district is 379 students.

Since a tuition tax credit would lower the price that parents pay for private schooling, it can be expected to shift the market demand schedule upward. If the demand schedule without a tax credit is,

(6) $q_{\mathrm{D}}=\mathrm{ap}^{-\beta}$

then the introduction of a tax credit would shift the demand schedule to,

(7) $\mathrm{q}_{\mathrm{D}}^{\prime}=\mathrm{a}(\mathrm{p}-\mathrm{t})-\beta$

where $t$ is the amount of the credit and $\beta$ is price elasticity of demand.
Figure 1 shows how the introduction of a tax credit would shift the demand function. The three schedules $D_{1}-D_{5}$ illustrate the position of the demand function after the introduction of tax credits amounting to $\$ 100, \$ 300$, and $\$ 500$ respectively. Since the supply schedule is upward sloping, a tuition tax credit can be expected to increase average tuition as well as private school enrollment. However, because the estimated supply schedule is very elastic, the increase in tuition would be relatively small, and the major effect of the tax credit would be to increase enrollment.

Table 2 shows the changes in tuition and enrollment that could be expected from the imposition of varying tax credit policies. (All calculations reflect 1980 dollar amounts). A $\$ 100$ tax credit would result in a 5.4 percent increase in enrollment and a 0.9 percent rise in tuition, while a $\$ 500$ tax credit would raise enrollment by 38 percent and tuition by 5.8 percent.

In North Carolina in 1980, there were about 57,000 students enrolled in private elementary and secondary schools, or about 4.4 percent of the state's total school-age population. A $\$ 500$ tuition tax credit would have increased enrollment in the state's private schools by 38 percent, or some 21,600 students. Private school enrollment would have increased from 4.4 percent to 6.1 percent of the total school-age population. Such an increase would not destroy the public schools, as some critics of tuition tax credits have charged, but it could cause significant adjustment problems.

In 1980, the pupil-instructional staff ratio in North Carolina public schools was 17.9. Thus, the transfer of 21,600 students to private schools could result in the potential elimination of 1,207 teaching positions in the public schools. While not all these positions would be lost (because average class size probably would be allowed to fall), some districts might face the necessity of significant staffing cuts.

More at issue, however, than the adjustment problems caused the public schools is the overall cost or benefits of such a program to taxpayers. A $\$ 500$ tax credit for taxpayers in North Carolina would cost the federal government $\$ 39.3$ million (i.e., $\$ 500 \times 78,600$ students) in lost revenue. In other words, it would cost the federal government $\$ 1,819$ (i.e., $\$ 39.3$ million $\div 21,600$ ) for each child transferred to private school. Average per pupil expenditure from all 
Figure 1.

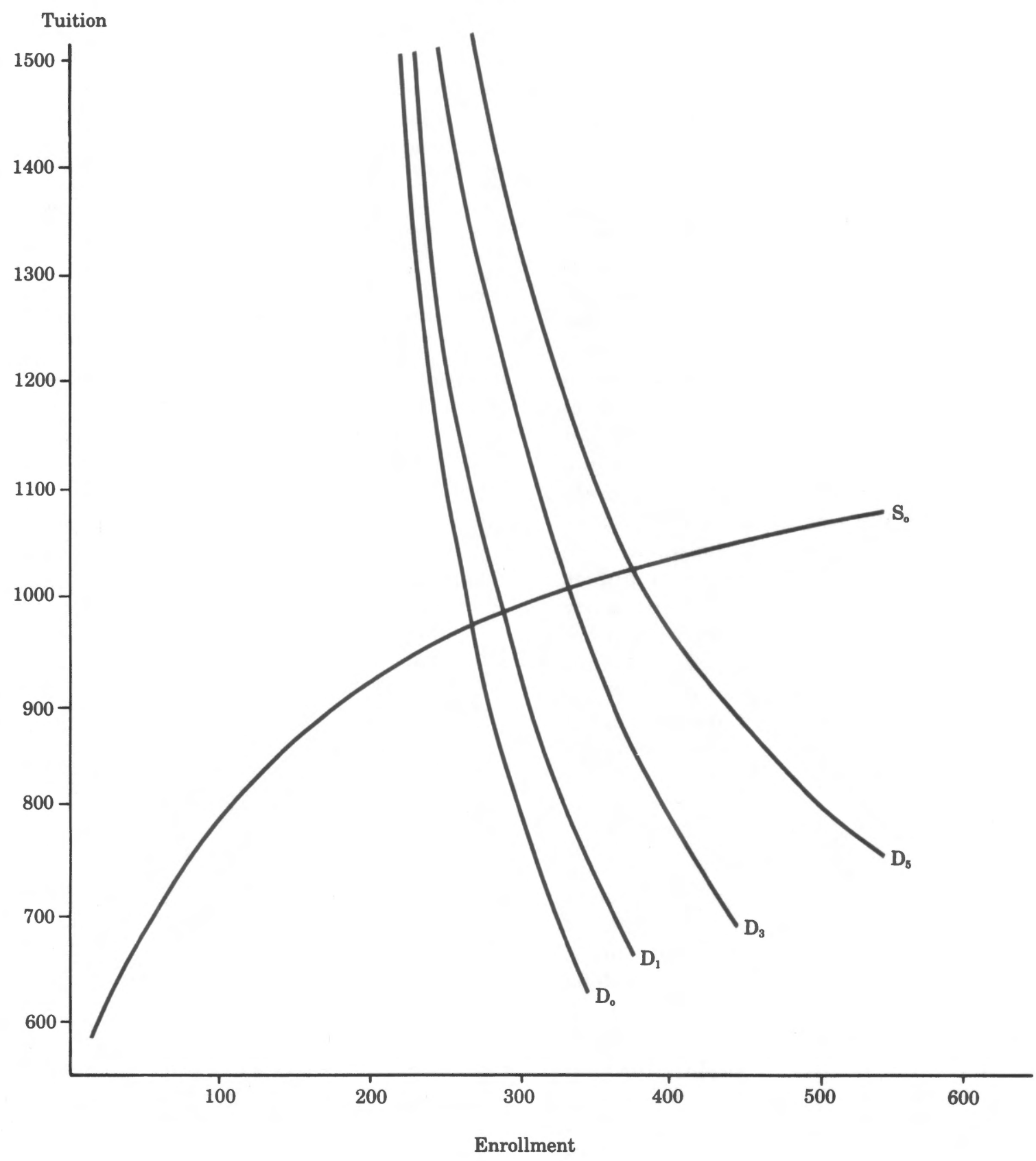

TALE 2.

Effects of Tuition Tax Credits

(in 1980 dollars)

\begin{tabular}{ccccc}
\hline & \multicolumn{2}{c}{ Equilibrium Values } & & $\begin{array}{c}\text { Percent Change* } \\
\text { in Tuition }\end{array}$ \\
\cline { 2 - 4 } Size of Credit & Tuition & Enrollment & & $\begin{array}{c}\text { Percent Change* } \\
\text { in Enrollment }\end{array}$ \\
\hline No credit & $\$ 966$ & 279 & - & - \\
$\$ 100$ credit & 975 & 294 & $0.9 \%$ & 5.4 \\
$\$ 300$ credit & 995 & 331 & 3.0 & 18.6 \\
$\$ 500$ credit & 1,022 & 385 & 5.8 & 38.0 \\
\hline
\end{tabular}

$* \%$ change from the no-credit base. 
sources in public schools in 1980 was $\$ 1,944$ (excluding debt service and capital costs). So if the entire savings in expenditures could be rebated to taxpayers, there would be a potential savings of $\$ 125$ per student or about $\$ 2.7$ million overall $(21,600 \times \$ 1,944-\$ 39.3$ million $){ }^{3}$

Whether the entire savings or only some lesser amount would actually accrue to taxpayers would depend on the ability of the public schools to cut expenditures in line with the drop in enrollment. This certainly would not be easy. But even if savings could actually be obtained, they would have to be balanced against the possible harm that such a publicly sanctioned transfer of students might do to program effectiveness and morale in the public schools. Proponents of tuition tax credits often argue that tax credits would create more competition and, thereby, cause the public schools to operate more efficiently. But since many of those transferred would likely be among the more motivated and disciplined students in public schools, their withdrawal might significantly lower average achievement and productivity in the public sector. Whatever the tax savings might be, one may still question whether the public interest would be served by encouraging the withdrawal of better students from public schools.

\section{IV.}

This paper has presented estimates of a model of market demand and supply for private schools. The price and income elasticities of demand were found to be in the inelastic range. The price elasticity was estimated to be -0.52 and the income elasticity to be 0.85 . The market supply of private schooling was found to be quite elastic: the elasticity of supply was estimated to be 5.88 .

The demand and supply model was used to simulate the effects of various tuition tax credits. It was estimated that a $\$ 500$ credit in 1980 would have resulted in a 38.0 percent increase in private school enrollment and a 5.8 percent increase in average tuition. Since average expenditure per pupil in public school was more than the average revenue loss per pupil trans- ferred to private school, there would have been a potential tax saving in North Carolina of $\$ 2.7$ million.

\section{FOOTNOTES}

${ }^{1}$ These data are published in Calvin L. Criner, Directory, Non-Public Schools in North Carolina, 1980-81 (Raleigh, NC.: Office of the Governor, Office of Non-Public Education, 1981).

2The variance of the error term was assumed to be $\mathrm{E}\left(\mathrm{e}^{2}\right)$ $=\delta^{2} / S_{i}$ where $\delta^{2}$ is a constant and $S_{i}$ is the total number of schools. In this case, weighting the observations in the regression equations by $S_{i}$ yields an equation with constant variance.

${ }^{3}$ Since the demand and supply functions in the estimated model are not linear, the savings will vary with the size of the credit. The following table shows the potential savings that might be expected depending on the size of the tax credit:

\begin{tabular}{|c|c|c|c|c|}
\hline $\begin{array}{c}\text { Tax } \\
\text { Credit }\end{array}$ & $\begin{array}{c}\text { Drop in } \\
\text { Public } \\
\text { School } \\
\text { Enrollment }\end{array}$ & $\begin{array}{l}\text { Savings from } \\
\text { Reduced } \\
\text { Public Sch. } \\
\text { Enrollment* }\end{array}$ & $\begin{array}{l}\text { Loss in } \\
\text { Fed. Tax } \\
\text { Revenue }\end{array}$ & $\begin{array}{l}\text { Net Gain } \\
\text { or (Loss) to } \\
\text { Taxpayers }\end{array}$ \\
\hline$\$ 10$ & & $\$ 5$, & 300 & $\$ 2$ \\
\hline 30 & & 20,610 & $20,280,600$ & 329,688 \\
\hline 50 & 21,660 & $42,107,040$ & $39,330,000$ & $2,777,040$ \\
\hline
\end{tabular}

*Calculated by multiplying the drop in public school enrollment times the average expenditure per pupil in public schools $(\$ 1,944)$.

\section{REFERENCES}

Armor, David J., "White Flight and the Future of School Desegregation," in School Desegregation by Walter G. Stephan and Joe R. Feagin eds. (New York: Plenum Press, 1980), 187-226.

Clotfelter, Charles T., "Urban School Desegregation and Declines in White Enrollment: A Reexamination," Journal of Urban Economics 6 (July 1979), 352-70.

Cohn, Elchanan, The Economics of Education (Cambridge, Mass.: Ballinger Publishing Company, 1979).

Coleman, James S., Sara Kelly, and John Moore, "Recent Trends in School Integration 1968-73," (Washington, DC Urban Institute Paper, 722-03-01, April 1975).

Criner, Calvin L., Directory, Non-Public Schools in North Carolina, 1980-81 (Raleigh, NC: Office of the Governor, Office of Non-Public Education, 1981).

Erekson, O. Homer, "Equity Targets in School Finance, Tuition Tax Credits, and the Public-Private Choice," Journal of Educational Finance 7 (Spring 1982), 436-49.

Frey Donand E., "The Cost of a Tuition Tax Credit Reconsidered in the Light of New Evidence," Journal of Educational Finance 7 (Spring 1982), 450-61.

Friedman, Milton and Rose Friedman, Free to Choose (New York: Avon Books, 1981).

New York Times, "A Torpedo for Public Education," (October 3, 1981), p. 20.

Niskanen, William A., "Considerations Affecting the Size of Cities and School Districts," Review of Social Economy 38 (December 1980), 337-38.

Rubinfeld, Daniel L., "Voting in Local Elections: A Micro Analysis," Review of Economics and Statistics 59 (February 1977$), 30-42$. 